\section{THE MUSEUM OF NATIONAL ANTIQUITIES OF FRANCE}

AL the French national museums are located in Paris A with the exception of the Museum of National Antiquities, which is at some distance from Paris, in a small town of the banlieue. Although the Château de Saint Germain, which has been allotted to that interesting and really national collection, is a very picturesque monument, and the forest round a favourite pleasure-ground for Parisian families, the site allotted to the museum about ten years ago was not selected with the view of giving an additional attraction to the place. But the very idea of collecting relics of prehistoric ages in order to demonstrate that our ancestors lived in the age of the so-called dilurian animals was opposed by a formidable number of influential people.

Napoleon III., personally a believer in the new theory, insisted upon the creation of the museum, but he assented to place it at St. Germain in order not to offend directly the prejudices of a formidable number of his supporters.

The St. Germain château was elegantly built in brickwork by Francis I., the king chevalier, who dedicated it to his fair dame, Diane de Poitiers. It was within its walls that Louis XIV. was born, and the government of the Mazarin was sitting in its elegant precincts when Paris was in the hands of the Fronde. Louis XIV. disregarded the building where his cradle had been surrounded by such dangers, and built Versailles with all its magnificence at a small distance of six miles. So St. Germain sank gradually from the dignity of a regal residence into the degrading condition of a prison for soldiers condemned to penal servitude by the Council of WVar of the First Military Division. The site was only famous as being the favourite spot where Alexander Dumas built his celebrated villa of Monte Christo, and the first place connected by a railway with Paris, as early as 1837 .

The opening of the museum was the inauguration of a new era for the castle of St. Germain. Reparations and restorations were begun with activity, and are proceeding with such zeal that in the course of two years hence they will be completed. During the Franco-German war St. Germain was a stronghold of the German armies besieging Paris, but the museum remained unmolested, having been taken by the Emperor William under his special protection, and M. Gabriel de Mortillet, the conservateur, who had remained at his post, took advantage of his influence to protect the inhabitants of the city with much energy.

His superior, the then Director of the Musenm, is M. Alexandre Bertrand, a brother to $M$. Joseph Bertrand, the present Perpetual Secretary of the Academy of Sciences. 'The museum is now placed under the control of the historical commission for constructing the Map of Gaul. This learned body is publishing a magnificent series of maps and engravings in order to illustrate the progress of the science of the prehistoric period, as well as of the Gälic, Roman, Gallo-Roman, and Merovingian. They are also manufacturing in the establishment models of the objects exhibited which cannot be sold for money, but are sent by the Government to the several provincial museums, or presented to learned men in consideration of objects given to the museum, so that they may be acquired by way of exchange. There is also in the establishment a special library in which have been collected by M. Gabriel de Mortillet all the books relating to prehistoric antiquities, and which is open free on certain days to the public. A carefully compiled catalogue has been prepared, and is to be published.

The establishment is in some respects connected with the Prehistoric Congress, M. Gabriel de Mortillet having originated the idea at La Spezzia, and M. Alexandre Bertrand or he having been delegated by the Govern. ment to all similar meetings which have taken place since that period. M. Alexandre Bertrand was delegated to Stockholm last year.

The objects collected in the galleries are very numerous, arranged in excellent order, and accompanied by inscrip tions sufficient for the perfect understanding of their historical bearings. A catalogue has been issued, and is sold at a small price by the porters.

In the basement have been located casts from the Trojan column for showing the arms and manner of the Romans when practising warfare.

In the same part of the building are to be found the models of Roman arms which were tried in the Polygon of the forest before the members of the Congress of Geography, as mentioned in our "Notes."

These apparatus were constructed by a French officer in order to elucidate questions raised by the publication of "La Vie de César," edited by Napoleon III., who had secured the collaboration of a number of eminent members of the Académie des Sciences Morales et Politiques. Two volumes of that altogether interesting and well-written book (although the theories of Cæsarism cannot be said to have borne the severe test of facts) have been published by M. Plon; the editor of his Imperial Majesty. The first sold immensely, as Napoleon III. was then at the zenith of his power; but the circulation of the second, issued a few months before the Franco-German war broke out, was very limited indeed-so limited that the editor prosecuted the Emperor to recover the money spent by him ; but the petition was discharged with costs.

It is for the publication of "La Vie de César" that the siege of Alesia, the crossing of the Rhine, \&c., have been expeditiously and carefully executed. The building of bridges over powerful streams, encampments established, assaults given, cities defended, all the warlike operations of the Romans, can be understood by a visit paid to the Museum of St. Germain. All this would have remained a mystery for thousands of visitors, as the museum is fast becoming a place of resort, if Napoleon III. had not felt it necessary to justify by historical arguments his theories on the advantages of the government of societies by men with a special destiny.

The large hall in the second floor may be said to be the most essential part of the museum. It contains the famous Moulin Guignon jaw and other human fossils discovered by Boucher de Perthes. In a glass case have been exposed seriatim the celebrated bones embellished by prehistoric artists with sculptures of the then living animals.

A magnificent bust of Boucher de Perthes, and another of Christy, the famous English banker and amateur geologist, have been erected side by side in a conspicuous place. It is a justice paid to their joint labours in the foundation of prehistoric science. It was due to the moral courage displayed when resisting the authorities, of such men as Cuvier, Elie de Beaumont, Buckland, and a number of other official geologists, and to the ingenuity displayed in the demonstration of such important facts.

On the walls have been painted magnificent maps exhibiting the distribution of caves and places where stone or bronze implements have been discovered, and the limits of the several Gallic tribes in existence when Cæsar invaded Gaul. A number of pictures al fresio are exhibited showing the several phases of prehistoric life, principally in lake-dwellings.

No such institution is to be found in England, although cave-hunting is becoming an important pursuit in the country of Lubbock, Lyell, Huxley, and Dawkins. A visit to St. Germain is a very useful way of spending a holiday, especially if the visitor has previously written a note to M. Gabriel de Mortillet, who is always ready to give kindly personal explanation to foreign visitors.

W. DE FONVIELIE 